\title{
THE SIMPLICITY OF SELF-KNOWLEDGE AFTER AVICENNA
}

\author{
PETER ADAMSON \\ Lehrstuhl VI für spätantike und arabische Philosophie, \\ Ludwig-Maximilians-Universität München, Geschwister-Scholl-Platz 1, \\ 80539 München, Germany \\ Email: peter.adamson@lrz.uni-muenchen.de
}

\begin{abstract}
Alongside his much-discussed theory that humans are permanently, if only tacitly, self-aware, Avicenna proposed that in actively conscious self-knowers the subject and object of thought are identical. He applies to both humans and God the slogan that the self-knower is "intellect, intellecting, and object of intellection ('aql, 'a qil, ma' qūl)". This paper examines reactions to this idea in the Islamic East from the 12th-13th centuries. A wide range of philosophers such as Abū l-Barakāt al-Baghdādī, Fahr al-Dīn al-Rāzī, al-Šahrastānī, Šaraf al-Dīn al-Mas 'ūdī, al-Abharī, al-Āmidī, and Nașīr al-Dīn al-Ṭūsī raised and countered objections to Avicenna's position. One central problem was that on widely accepted definitions of knowledge - according to which knowledge is representational or consists in a relation - it seems impossible for the subject and object of knowledge to be the same. Responses to this difficulty included the idea that a self-knower is "present" to itself, or that here subject and object are different only in "aspect (i 'tibār)".
\end{abstract}

Résumé. Au cours de son exposé de sa thèse si disputée selon laquelle les êtres humains sont de manière permanente, fût-ce tacitement, conscients d'eux-mêmes, Avicenne suggère que dans les auto-connaissants activement conscients, le sujet et l'objet de la pensée sont identiques. Il applique alors - à la fois aux êtres humains et à Dieu le slogan affirmant que l'auto-connaissant est « intellect, intelligeant et intelligé » ('aql, 'āqil, ma 'qūl). Cet article examine les réactions à cette idée dans l'Est du monde islamique durant les 12 ème et 13 ème siècles. Un grand nombre de philosophes, tels Abū l-Barakāt al-Baghdādī, Fahr al-Dīn al-Rāzī, al-Šahrastān̄̄, Šaraf al-Dīn al-Mas ‘ūdī, alAbharī, al-Āmidī et Nașīr al-Dīn al-Ṭūsī ont en effet soulevé des objections à l'encontre de la position d'Avicenne et ont apporté des réponses à ces objections. Un problème central a consisté dans le fait que selon des définitions généralement acceptées de la connaissance - d'après lesquelles la connaissance est représentationnelle ou consiste dans une relation -, il paraissait impossible pour le sujet et l'objet de la connaissance d'être le même. Des réponses à cette difficulté ont mis en place l'idée que tout autoconnaissant est « présent » à soi, ou que dans ce cas, le sujet et l'objet sont différents seulement selon l' « aspect » (i 'tibār $)$.

Though Avicenna (Ibn Sīnā, d. 1037) is often called a "Neoplatonist" in fact he rejects one of the most striking features of the Neoplatonic system, the postulation of a First Principle that is beyond intellect. Like Aristotle's god the Avicennan Necessary Existent thinks about itself, and in so doing causes and knows all other things. Because of the prominence of committed Aristotelians like al- 
Fārābī, Averroes, and Avicenna himself in our historiography, it may seem that this is the standard view among the Greek-inspired thinkers known as faläsifa. In fact though, some thinkers in the Islamic world who drew on Greek sources rejected the thesis that God engages in intellection. ${ }^{1}$ And for good reason. What the Neoplatonists had secured by making their First Principle transcend intellective thought was nothing less than His perfect simplicity, and one of the primary goals of Muslim, Christian and Jewish falāsifa was precisely to safeguard divine oneness (tawhìd) using philosophical argumentation. Thus already alKindī contends in his On First Philosophy that God, the "true One", cannot be intellect because intellect grasps multiple universal objects. ${ }^{2}$

Here al-Kindī is of course following Plotinus, but mentioning only one of two reasons given by the latter for associating intellect with multiplicity. The other reason is that, in knowing itself, intellect is subject to a duality of subject and object. It is thus both the same as and different from itself ${ }^{3}$ :

Enn. 5.1.4.30-3: [Being and intellect] occur together and never leave one another, but this one is two things together, intellect and being, thinking and object of thought, intel-

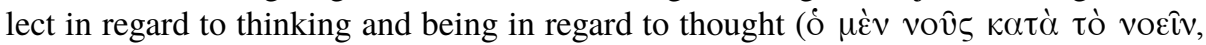

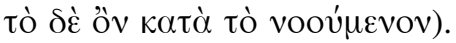

Though the Plotinan intellect is marked by duality, it is also the most perfect case of self-thinking. As one scholar has aptly put it, "the universal Intellect is the only stage in the Plotinian hierarchy where identity of subject and object of cognition, complete knowledge of the ontologically primary things themselves, and self-knowledge obtain."4

In this sense, Plotinus was in fact adopting the Aristotelian idea of a divine, self-thinking intellect, despite his refusal to give this intellect the status of First Cause. He may have been particularly influenced by the version of the theory found in the second century AD commentator Alexander of Aphrodisias, who

${ }^{1}$ As I've pointed out elsewhere, this is even more true of the thesis that the universe is eternal, which was accepted by the handful of famous names who belonged to the Aristotelian vanguard but rejected by a wide spectrum of thinkers across falsafa and kaläm. See P. Adamson, "Eternity in Medieval Philosophy", in Eternity: a History, ed. Y. Melamed (Oxford, Oxford University Press, 2016), 75-116.

${ }^{2}$ See P. Adamson and P. E. Pormann, The Philosophical Works of al-Kindī (Karachi, 2012), 49.

${ }^{3}$ For the point put explicitly in terms of sameness and difference, see e. g. Enn. 6.7.39.4-7. As observed with regard to this passage by I. Crystal, "Plotinus on the Structure of SelfIntellection", Phronesis 43 (1998): 264-86, at 278, this is one way that Plotinus connects the "greatest kinds" of Plato's Sophist (which include sameness and difference) to the nature of intellect.

${ }^{4}$ E. K. Emilsson, Plotinus on Intellect (Oxford, 2007), 142. 
will also be key in the transmission of the doctrine to the Islamic world. In his treatise On Intellect, Alexander writes:

For simple intellect thinks something simple, there being no object of thought that is simple apart from it... Therefore, insofar as it is intellect, it thinks itself as object of thought; insofar as it is also intellect in actuality and is object of thought, it always thinks itself; but insofar as it alone is simple, it thinks itself alone. For being the only

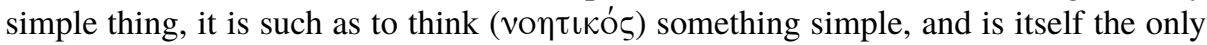
simple thing among objects of intellection. ${ }^{5}$

Notice that here, Alexander insists that the self-thinking intellect is indeed "simple", and not a "one-many" as Plotinus would put it. A great deal turns on this apparently minor disagreement. For Avicenna too, no less than Plotinus or al-Kindī, will want to say that God is indeed simple. Indeed, as we will see shortly God is a self-thinking intellect precisely because $\mathrm{He}$ is simple, a purely immaterial being who lacks even connections to matter. So if it turns out that self-knowledge requires a degree of multiplicity, however minimal, Avicenna will have to retreat from his Aristotelian vision of God as an intellect.

That vision involves a parallel drawn by Avicenna between God's selfknowledge and humans' cognition of themselves. As much recent research has stressed, Avicenna was a pioneer in the theory of self-awareness, and put this idea at the center of his account of the human soul and even personal identity. ${ }^{6}$ One of the topics of debate in the literature on this aspect of his thought has been the question whether it is indeed intellect, or some other power of the soul, that is responsible for self-awareness. ${ }^{7}$ So one might wonder whether it is problematic to

${ }^{5}$ I. Bruns (ed.), Alexandri Aphrodisiensis scripta minora (Berlin, 1887), 109.28-110.3. For an English translation of the work see F. M. Schroeder and R. B. Todd, Two Aristotelian Commentators on the Intellect (Toronto, 1990).

6 Studies on this topic include A. Hasnawi, "La conscience de soi chez Avicenne et Descartes" in J. Biard and R. Rashed (eds.), Descartes et le Moyen Âge (Paris, 1997), 283-91; J. Kaukua and T. Kukkonen, "Sense-Perception and Self-Awareness: Before and After Avicenna", in S. Heinämaa, V. Lähteenmäki and P. Remes (eds), Consciousness: from Perception to Reflection in the History of Philosophy (Dordrecht, 2007), 95-119; D. L. Black, "Avicenna on Self-Awareness and Knowing that One Knows", in S. Rahman et al. (eds), The Unity of Science in the Arabic Tradition (Dordrecht, 2008), 63-87; L. X. López-Farjeat, "Self-Awareness ( $\check{s} u$ 'ūr bi-al-dāat) in Human and Non-Human Animals in Avicenna's Psychological Writings", in A. G. Vigo (ed.), Oikeiosis and the Natural Bases of Morality: From Classical Stoicism to Modern Philosophy (Hildesheim, 2012), 121-40; J. Kaukua, Self-Awareness in Islamic Philosophy: Avicenna and Beyond (Cambridge, 2015). I will not discuss here the most famous passage invoking self-awareness, the "flying man" thought experiment. For this see however P. Adamson and F. Benevich, "The Thought Experimental Method: Avicenna's Flying Man Argument", Journal of the American Philosophical Association (2018).

${ }^{7}$ S. Pines, "La conception de la conscience de soi chez Avicenna et chez Abu'l-Barakat alBaghdād̄̄", in S. Pines, Studies in Abu l-Barakāt al-Baghdādī: Physics and Metaphysics 
alternate between speaking of self-awareness and speaking of self-knowledge or self-intellection, as I have been doing thus far. But as we'll see, these concepts were used interchangeably in a debate inspired by Avicenna. In what follows, I'll be charting the development of this debate over about two centuries of postAvicennan thought, beginning with his most famous critic al-Ghazālì (d. 1111) and ending with the group gathered around Nașīr al-Dīn al-Ṭ̂̀sī (d. 1274) at Marāgha. ${ }^{8}$ While some thinkers attempted to defend Avicenna's position, others raised doubts as to whether the subject of knowledge could really be fully identical with the object of that same knowledge.

\section{AVICENNA'S POSITION}

Thus far I have been following Plotinus by suggesting that, if self-knowledge does imply multiplicity, it implies duality. But in an influential passage Avicenna actually identifies not two but three aspects that belong to the self-thinking soul:

The soul conceives itself, and its conceiving itself makes it intellect, intellecting, and object of intellection ('aql, 'áqil, ma' $q \bar{u} l$ ). But its conceiving these forms does not make it like this, because in its substance in the body, it is always potential intellect, even if it becomes actual with respect to some things. ${ }^{9}$

The threefold characterization goes all the way back to Aristotle himself (it

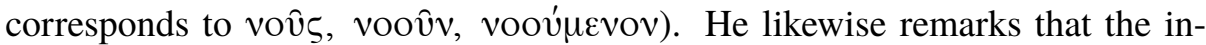
tellective power of the soul is at first potential (De Anima 429 b 6-9), both in respect of grasping particular objects distinct from itself, and in grasping itself. The idea here would seem to be that the human intellect can always grasp itself as that which is grasping something else; thus if I think about what triangle is, I can also grasp my mind as the subject of that thought.

Furthermore, Aristotle ties the intelligibility of the intellect to its immateriality: it "is an object of intellection just like [other] objects of intellection.

(Jerusalem, 1979), 181-258, at 211, concludes that Avicenna's considered view is that intellect is the relevant faculty.

${ }^{8}$ For reasons of space, my analysis will not include contributions from the "Illuminationist" tradition inaugurated by Suhrawardī (d. 1191). Yet the material covered in this paper (especially in section 4) provides part of the context in which Illuminationist philosophy developed, notably the concept of knowledge by presence. On the latter and its relevance to self-knowledge see H. Eichner, “'Knowledge by Presence', Apperception and the Mind-Body Relationship: Fahr al-Dīn al-Rāzī and al-Suhrawardī as Representatives and Precursors of a ThirteenthCentury Discussion", in P. Adamson (ed.), In the Age of Averroes: Arabic Philosophy in the Sixth / Twelfth Century (London, Warburg Institute, 2011), 117-40.

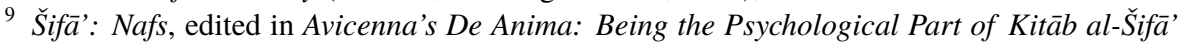
(London, 1959), 239.7-10. 
For regarding those things that have no matter, the intellecting and object of

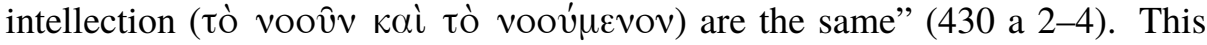
provides Avicenna with a rationale for ascribing intellection to God, since $\mathrm{He}$ is of course immaterial, as we can infer from His necessary existence, given that matter would be a cause and the Necessary Existent can have no causes. In Metaphysics 12.9, Aristotle claims that in divine self-thought intellection is permanent, and involves identity between the subject and object of intellection (1075 a 5) ${ }^{10}$ In agreement with this, Avicenna writes in his Išārāt:

The First is the object of intellection for Himself ( $m a$ ' $q \bar{u} l a l-\underline{d} \bar{a} t)$ and what subsists for Himself. For He subsists free from attachments, lacks, or materials, and anything else that would bestow an addition onto the essence. And you know that what is like this intellects itself and is intellected by itself. ${ }^{11}$

The argument may strike us as rather odd: Avicenna treats self-intellection as a kind of "default" condition. Any self-subsisting thing, he contends, will engage in self-directed thought unless it is impeded from doing so, the possible impediment being matter. It is only a negative feature of God, namely His lack of any connection to matter, that explains why He has Himself as an object of thought. For, given that $\mathrm{He}$ is immaterial, $\mathrm{He}$ is not just engaged in intellection but also something that can be the object of intellectual thought, as Aristotle too had said. ${ }^{12}$

Avicenna makes the same point more expansively, and with an echo of the claim made above concerning the human soul, in the $\check{S} i f \bar{a}$ ':

The Necessary Existent is pure intellect, because He is an essence ( $\underline{d} \bar{a} t)$ that is apart from matter in every way. You already know that the reason for not grasping something intellectually is matter and its attachments... Thus whatever is free of matter and [its] attachments is realized through an existence apart from [matter]: it is that which is an intelligible object for itself (huwa ma'qūl li-dattihi). Because it is an intellect in itself (bi-dâtihi) it is also an intelligible object in itself, so it is its own intelligible object ( $\mathrm{fa}$ huwa ma 'qül d्ātihi). Thus its essence is intellect, intellecting, and intelligible object ('aql, 'āqil, ma' $q \bar{u} l)$, without there being a multiplicity of things here. ${ }^{13}$

${ }^{10}$ For more on this chain of argument see P. Adamson, "Avicenna and his Commentators on Self-Intellective Substances", in D. N. Hasse and A. Bertolacci (eds), The Arabic, Hebrew and Latin Reception of Avicenna's Metaphysics (Berlin, de Gruyter, 2011), 97-122; on inferring immateriality and other attributes from the concept of necessary existence, see P. Adamson "From the Necessary Existent to God", in P. Adamson (ed.), Interpreting Avicenna: Critical Essays (Cambridge, 2013), 170-89.

11 al-Išărāt wa-l-tanbīhāt ma'a Šarh Nașìr al-Dīn al-Ṭūsì, ed. S. Dunya, 4 vols (Cairo, Dār al-Ma'ārif, 1957-1960), vol. 3, p. 53.

12 As Kaukua and Kukkonen, "Sense-Perception and Self-Awareness", p. 110, put it, in the human case too "the soul's immateriality enables it to function as an object of intellectual perception" which is why it "can have primitive self-awareness as an object of reflection". 
But of course what we want to know is precisely the rationale for the final claim here, namely that God's being subject of thought, thinker, and object of thought (or knower, knowing, and known), introduces no multiplicity into Him. That rationale comes in the next chapter of the metaphysical part of the Šifä':

The mere fact that $\mathrm{He}$ is both intelligible object and intellecting does not imply that $\mathrm{He}$ is two in essence $(\underline{d} \bar{a} t)$, nor even that He is two in aspect $\left(f \bar{i} l-i{ }^{i} t i b \bar{a} r\right)$. For the occurrence of the two things is nothing more than the consideration ( $\left.i{ }^{\prime} t i b \bar{a} r\right)$ that there is a quiddity existing due to itself (li-d̄atihi), and that $\mathrm{He}$ is a separate quiddity, to which His essence belongs. ${ }^{14}$

Again, the same goes for the human case:

When you are aware of yourself, it is necessary that there is in this case an identity (huwiyya) between the subject and object of awareness. ${ }^{15}$

Here we see the importance of Avicenna's making self-intellection a default condition. Since the phenomenon is explained solely in terms of the absence of an impediment, it implies no superadded feature or activity. Obviously this is especially important in the case of God, since it means that His oneness is not undermined by His self-thinking. ${ }^{16}$

\section{INITIAL CRITICISMS}

It seems all but obligatory to begin our considerations of critical reactions to the Avicennan theory with al-Ghazâlī’s Tahäfut al-falāsifa. On Avicenna's behalf, he rehearses the "default" argument that God must be a self-thinker if $\mathrm{He}$ is immaterial, and restates the claim that God is 'aql, 'a $q i l$, and $m a$ ' $q \bar{u} l .{ }^{17}$ The same goes for humans, with the caveat that their self-knowledge is intermittent whereas God's is permanent. For the most part, al-Ghazālì's criticism of

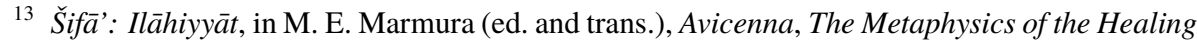
(Provo, 2005), §8.6.6-7. Translation of this passage and many other passages to follow in this paper is bedeviled by the possibility of rendering $\underline{d} \bar{a} t$ as either "essence" or "self". For the most part I will use "self", but the reader should bear the ambiguity in mind.

${ }_{14}$ Šifä', Ilāhiyyāt $\$ 8.6 .12$.

15 al-Ta 'lìqāt, ed. A. R. Badawì (Cairo, 1973), 147.23. The comparison between God and human is underlined at Šifä', Ilāhiyyāt §8.7.1 with an explicit back reference to the Nafs of the Šifä'.

${ }^{16}$ For the compatibility of negative features and simplicity see e. g. Išărāt, vol. 3, p. 285: "a multiplicity of concomitants (lawäzim) belongs to the First, both relative and non-relative, and a multiplicity of negations, and for this reason a multiplicity of names. But from this there is no effect on the unity of His essence." See also Šifä': Ilähiyyāt, §8.4.2, §8.7.12.

17 M. E. Marmura (ed. and trans.), Al-Ghazālì: The Incoherence of the Philosophers (Provo, 1997), §5.24. 
Avicenna regarding divine cognition has to do with the idea that the Necessary Existent will know Himself by knowing that $\mathrm{He}$ is the cause of other things. ${ }^{18}$ But at one point he also gives an argument more germane to our concerns:

Tahăfut §6.50-1: If you say that [His self-knowledge] is identical to Him, then what is the difference between you and one who says that a human's self-knowledge is identical to his self? This is folly. For one may suppose the existence of his self while he is in a state of being oblivious to his self, and then his obliviousness ceases and he is alerted to his self; thus his awareness of his self is doubtless not his self. [...] The fact that the First is eternally self-knowing does not show that His self-knowledge is identical with He Himself. Supposition can go so far as to posit [His] self and then the arising of [self-]awareness. If the latter were identical with He Himself, then this supposition (tawahhum) could not be conceived.

The passage concerns the identity of the knower and the act of knowledge, not the identity of knower and known, but it thereby obviously bears on our question of the simplicity of the self-knower. His first criticism exploits the parallel Avicenna keeps drawing between human and divine self-knowledge. If we are indeed talking about fully actual, aware self-thinking, then we must recognize that in humans this comes and goes, whereas of course a human's identity with him- or herself is not intermittent. Thus actual self-thinking cannot be identical to the person's self; why then think that God's case should be any different? ${ }^{19}$ With his usual dialectical acuity, al-Ghazālī here turns against Avicenna his assumption that human and divine self-cognition are akin. Having said that, the second criticism seems rather less formidable. Al-Ghazâlī argues that, if we can imagine God as having a self without (yet) thinking about Himself, then His self and His self-thinking must be distinct. Avicenna would, presumably, simply respond that the conceptual distinction being made here has no basis in reality. Indeed al-Ghazālī almost seems to be inviting this response, given his use of the term tawahhum, which may have the sense of an unreliable supposition.

A more extensive critique of the Avicennan position is found in al-Šahrastānī. Rejecting as unpersuasive the "default" rationale for God's self-intellection, he writes:

Avicenna says that the Necessary Existent is through Himself intellect, intellecting, and intelligible object ('aql, 'a $q i l, m a$ ' $q \bar{u} l$ ), but is one in Himself ( $\underline{d} \bar{a} t)$ without being ren-

${ }^{18}$ Tahăfut $\S 6.22-53$. At $\S 12.8$ he goes so far as to say, "necessarily they must deny His selfknowledge, since there is no proof of this at all apart from will, and no proof of will apart from the creation of the world."

${ }^{19}$ For the idea that the human is identical with a tacit (that is, not fully conscious) self-awareness, see Black, "Avicenna on Self-Awareness". In this paper I will not explore the post-Avicennan reaction to the idea of permanently tacit self-awareness, but see for instance al-Mas'ūdī's $\breve{S} u k \bar{u} k$, in A. Shihadeh, Doubts on Avicenna: a study and edition of Sharafal-Dīn al-Mas 'ūdì's Commentary on the Ishärāt (Leiden, 2016), 214, for a statement that people who are asleep or drunk are not in some sense self-aware, as Avicenna had claimed. 
dered multiple. [...] You stipulated three notions ( $\left.i^{\prime} t i b \bar{a} r \bar{a} t\right)$ in the essence ( $\left.\underline{d} \bar{a} t\right)$ of the Necessary Existent, and explained each notion with its own meaning, none of which is understood from the others. This is patent Trinitarianism... [which] follows from asserting multiplicity of His essence in respect of one notion and another, just as it follows for the Christians in respect of one Person and another. [...] If existence, quiddity, separateness, intellection, and origination are synonymous expressions, allow that one of them may stand in the place of another, saying that separateness is intellection and intellection is origination, therefore separateness is origination! Or, if the expressions are distinct, allow that each expression signifies an idea which the other expression does not signify - and that is multiplicity! ${ }^{20}$

He seeks to impale Avicenna on the horns of a dilemma. Either God's immateriality is just the same as His self-thought and the origination of the universe that results from His self-thinking - which is absurd since these are obviously different, and cannot be used interchangeably - or these things are different. ${ }^{21}$ In the latter case we do have multiplicity in God, one that is suspiciously close to the Christian doctrine of the Trinity.

Al-Šahrastān̄ is onto something here. There was indeed precedent for the description of God as 'aql, 'aqqil, and ma'qūl in defending the doctrine of the Trinity. We find the Christian philosopher Yahyā Ibn 'Adī (d. 974) writing:

It has become clear that there is a comparison between intellect, intellecting, and object of intellection on the one hand, and Father, Son and Holy Spirit on the other, insofar as the substance of the intellect is the essence $(\underline{d} \bar{a} t)$ of that which is intellecting and the essence of the object of intellection, given that the object of intellection is a single essence with the intellect. They are not multiple, insofar as they are [one] essence, and they are just described with three attributes (sifät) each of which is distinct from the other two. So this essence is rendered multiple with regard to its three attributes, not in respect of its essence. ${ }^{22}$

${ }^{20}$ al-Šahrastānī, Mușāra' $a$, in W. Madelung and T. Mayer (ed. and trans.), Struggling with the Philosopher: a Refutation of Avicenna's Metaphysics (London, 2001). This is their translation, modified, of the passages at 68.3-4, 72.2-6, and 73.5-9.

${ }^{21}$ A very similar argument is found in the Mu 'tazilite author Ibn al-Malāhimīi (d. 1141). See H. Ansari and W. Madelung (eds), Tuhfat al-mutakallimīn fì l-rass 'alä l-falāsifa (Tehran, 2008), 72.14-19: "They apply to the Creator their assertion that intellect, intellecting, and intelligible object are one thing, saying that $\mathrm{He}$ is one in all respects so that multiplicity is impossible for Him in every way. Then they say that the exalted knows Himself $(\underline{d} \bar{t} t)$ and is Himself His own intelligible object. Sometimes they explain this by saying that He Himself is an intellect, that $\mathrm{He}$ is intellecting of Himself, and is Himself His own intelligible object, by which they mean that He knows Himself, and is Himself what He knows. So if they make knowledge one thing, the knower another, and the known a third thing, then they will be forced to say - if indeed He is Himself knowledge, knows Himself, and is Himself what He knows - that there are three things, and this will be a multiplicity in His essence $(\underline{d} \bar{a} t) . "$

22 A. Périer (ed. and trans.), Petite traités apologétiques de Yahyā ben 'Ad̄̄ (Paris, 1920), 21.622.3. 
From a Christian point of view, the Plotinian contention that divine selfthinking would involve a multiplicity within unity was entirely welcome, especially if the multiplicity in question turned out to be threefold. For Avicenna though, the consequence would be disastrous, not only because the last thing any Muslim intellectual wanted was to be found agreeing with Christians on this score, but also because of his own commitment to God's utter simplicity.

\section{SELF-KNOWLEDGE AS REPRESENTATION}

Despite these problems, philosophers in the Islamic East did not abandon the idea that humans and God are capable of genuine self-knowledge. Certainly there was widespread agreement that God can somehow know Himself despite being perfectly one. Though there was certainly dispute about the extent of God's knowledge, it tended to concern His knowledge of created things rather than whether He is capable of knowing Himself. As for us humans, a powerful boost to the idea that we are fundamentally self-aware or self-knowing beings came from Abū l-Barakāt al-Baghdādī (d. 1164/5). As has been shown in previous literature, he agreed with Avicenna that all cognition belongs to an implicitly self-aware subject, a subject who can always be actively aware of him or herself by reflecting on that very cognitive activity. ${ }^{23}$ Again in agreement with Avicenna, he concedes that fully conscious self-awareness is intermittent:

We are aware of ourselves, and know that the soul is cognizant of ( $t a$ ' rifu) itself, at one time paying attention to itself along with other things of which it is cognizant, at other times paying no attention. The case here is as with other objects of attention (mahf $\bar{u} \bar{u} \bar{a} t$ ) in that they may come to the attention or not. ${ }^{24}$

He argues that tacit self-awareness gives subjectivity to experience, that is, makes each of my experiences seem as though it belongs to me:

The person is aware of himself along with every pleasure and pain, knowledge, cognizance, perception, and consideration that proceeds from himself, whenever he is considering his state and activity. If this were not so, then he would not be aware, regarding his pleasure, of anything more than that it is pleasure. But the fact that it is his pleasure is something of which he is aware through the pleasure and enjoyment in the pleasure; likewise for pain and suffering pain. ${ }^{25}$

${ }^{23}$ S. Pines, "La conception de la conscience de soi chez Avicenna et chez Abu'l-Barakat alBaghdādī”, in S. Pines, Studies in Abu l-Barakāt al-Baghdādī: Physics and Metaphysics (Jerusalem, 1979), 181-258; J. Kaukua, "Self, Agent, Soul: Abū l-Barakāt al-Baghdādī’s Critical Reception of Avicennian Psychology”, in J. Kaukua and T. Ekenberg (eds), Subjectivity and Selfhood in Medieval and Early Modern Philosophy (Cham, 2016), 75-89.

${ }^{24}$ Kitāb al-Mu'tabar fì l-hikma, ed. S. Yaltkaya, 3 vols (Hyderabad, 1938-39), vol. 3, 90.20-22. See also vol. 2, 359.24-360.4. 
The example suggests that, alongside Avicenna's discussion of self-awareness, an inspiration for Abū l-Barakāt's theory may have been Plato's Timaeus, which also thematizes conscious awareness of pleasure and pain $(64 \mathrm{c}-\mathrm{d})$. Admittedly, there the point is somewhat different. Plato contrasted rapid processes of disruption or restoration of the body, which are consciously registered as pain and pleasure, with those that are too gradual to come to our active awareness. Humans then differ from God in that they are not always actively aware of themselves, but they can certainly become actively aware and when they do, the resulting self-perception is not unlike God's permanent self-intellection.

The upshot was that, moving into the late twelfth and thirteenth centuries, the question was not so much whether humans and God know themselves, but how exactly such knowledge works and whether it does compromise the simplicity of the knower. One way to approach these issues was to ask what knowledge is in general and then discuss whether self-knowledge fits the resulting account, or instead proves to be an exceptional, sui generis sort of cognition. Avicenna's theory of knowledge was (fairly or not) taken to be representationalist. In other words, someone knows something by receiving a form, impression, or likeness of that thing. As Fahr al-Dīn al-Rāzī (d. 1210) observes, ${ }^{26}$ it seems strange to suppose that self-knowledge could function in this way:

As for the theory that [knowledge] is equivalent to the occurrence ( $h u s \bar{u} l)$ of the quiddity of the known to the knower, [self-knowledge is problematic] because if what occurs to the agent of intellection is other than himself [self-knowledge] is undermined, for two reasons. First, because this other thing must be equal to what is known in the perfection of its quiddity. But then would follow the co-occurrence of indiscernibles (ijtima $\bar{a}^{\prime}$ almithlayn). Besides which, it is not more appropriate for either of them to be the intellect while the other is the object of intellection, than the other way around. Second, because when the knower knows that that form is equal to himself, his self-knowledge occurs before the occurrence of that form; or he does not know this, but then he is not selfknowing. But if [what he knows] is not the same as himself, then something is related to itself. ${ }^{27}$

That last point is meant to constitute a refutation, because Fahr al-Dīn takes it to be absurd that self-knowledge is a relation between a thing and itself. This is an assumption we will meet again below.

Though al-Rāzī counts two, there are actually three problems identified here. First, if one received oneself as an object of knowledge the way one receives other objects of knowledge, then two exactly similar things would "co-occur",

${ }^{25}$ Kitāb al-Mu'tabar fì l-hikma, vol. 3, 92.2-5.

${ }^{26}$ Fahr al-Dīn's treatment of self-knowledge is also discussed briefly by Eichner, "Knowledge by Presence", 125.

${ }^{27}$ Mulahhas fì l-hikma wa-l-mantiq, ms. Berlin Staatsbibliothek or. Oct. 623, fol. 118r, 1. 12-19. 
which is impossible because of the identity of indiscernibles. ${ }^{28}$ Second, even if we assume that two exactly similar things can co-occur, neither has a better claim to be the knower as opposed to the known. Third, in order to know that one is really knowing oneself, one must already know oneself - how else would one be sure that the object of knowing really is the self? With these objections Fahr alDīn is supposing that in self-knowledge, the self really needs to take itself on as an object, so that we would have for instance Peter turning up in Peter's own mind as that which is known. While that does seem problematic for the reasons Fahr al-Dīn has identified, it is no good saying that something other than Peter turns up in Peter's mind, since then Peter will not really be self-knowing. A spirited response to these concerns was later put forward by Athīr al-Dīn al-Abharī (d. 1264). He defends the Avicennan formula that the self-knower is 'aql, 'aqqil, and $m a$ 'qūl and shows how Fahr al-Dīn's objections can be avoided, so long as we do take the self qua object of knowledge to be representational, rather than saying that the self is reduplicated when it is received by the self, with the two versions of the self being, as Fahr al-Dīn puts it, "equal... in the perfection of quiddity". 29

A similar set of worries, with a different solution, is found in Sayf al-Dīn al-Ämidī (d. 1233). The relevant passage is found in the midst of a discussion about whether God has attributes additional to His essence; so here the issue is specifically divine self-knowledge, and we therefore have the constraint that the self-knower cannot be in any way multiple. Like Fahr al-Dīn, al-Āmidī points out that it is problematic to suppose that self-knowledge is representational:

If [God] knew anything, He would know that He knows this thing, but this is impossible for two reasons. First, because it would follow from this that He is self-knowing,

${ }^{28}$ A similar argument is used by Avicenna, and considered by Fahr al-Dīn, in discussing space. There the claim is that there can be no distinct spatial magnitude occupied by a body, since the dimensions of the body would be indiscernible from that magnitude. See on this P. Adamson, "Fahr al-Dīn al-Rāzī on Place", Arabic Sciences and Philosophy 27 (2017): 205-36.

${ }^{29}$ See also al-Abharī, Kašf al-ḥaqa'iq fì tahrīr al-daqā'iq, ed. H. Sarığlu (Istanbul, 1998), 339.4-15: "Investigation regarding the intellect, intellecting, and object of intellection: it is well known that when that which is separate grasps its proper self (d̄atahu al-mahșūsa) intellectually, no further form arises in it. Otherwise two indiscernibles would co-occur, such that neither of them would be more appropriately the subject of inherence, while the other is that which inheres in it. Thus the self, insofar as it is separate, is intellect; insofar as it is perceptive it is engaging in intellection; and insofar as it is perceived it is object of intellection. So every separate thing is intellect, engaged in intellection, and object of intellection. We do not concede that neither of the two is more appropriate to be the subject of inherence than the other. For one of them is an individuated self-subsistent form (șura šahsiyya qua' 'ima bi$n a f s i h \bar{a}$ ), whereas the other is an image (mithāl) which corresponds to it and is inscribed in it. The self-subsistent is more appropriate to be the subject of inherence. Hence, when something separate perceives itself nothing prevents that this happens through the inscribing of its own form in it." 
as mentioned above, but knowledge about something means nothing other than the impression of the form of what is known in the soul of the knower, or a relation between the knower and the known. On either assumption distinction would arise, but there is neither distinction nor numerical difference in the essence of God - may He be exalted. Second, because it would follow that He knows that He is knowing that He is knowing, and so on to infinity, which is absurd, because it involves a regress. ${ }^{30}$

His solution is simply to admit that self-knowledge is something additional to God, namely an "attribute":

Knowledge is an existing attribute added to the essence (sifa wujudiyya zầ'ida 'ala $l$ $\underline{d} \bar{a} t)$. It is not the same as imprinting or a relation that arises between the essence of the knower and what is known, rather it is [indeed] a connection and a relation, but only between the attribute of knowledge and what is known. On this basis, it is not impossible that His essence ( $\underline{d} \bar{a} t)$ knows itself, since it would mean that the attribute of knowledge subsists in His essence, and that attribute would be connected to the essence itself just as it is connected with all other objects of knowledge. ${ }^{31}$

So here we see a doctrine familiar from kalām being used to solve a problem deriving from Avicenna's philosophy. Since many mutakallimūn, especially Aš'arites, were prepared to say that God's tawhīd would not be violated by His possession of attributes, God's self-knowledge can be put in this category of things "additional" to the essence.

In the passage just cited, al-Āmidī rejects the notion that self-knowledge could

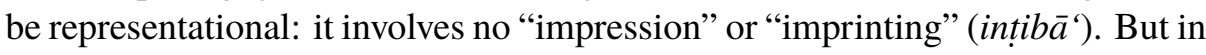
another work, he seems to accept that in humans at least, self-knowledge could conform to Avicennan representationalist epistemology. Probably this is because there is no tawhìd constraint in the human case. Nonetheless, he affirms in this context too that the knowledge in question will be in some sense "additional" to the knower. Here is his response to Fahr al-Dīn's complaint that self-knowledge would involve either a co-occurrence of two identical things, or a failure to have genuine identity between knower and known:

[R $\bar{a} z \bar{l}]$ says: it is distinctive to intellectual perceptions that they involve either our grasping our very selves intellectually, or grasping something additional to our selves.

We say: in fact it is something additional.

He says: the additional [form in the mind] is either equal to the quiddity of that thing or not [and neither is possible].

We say: it is equal in true reality but not in existence. For the existence of one of them is intellectual, whereas that of the other is concrete. It does not follow on this basis that the

\footnotetext{
${ }^{30}$ Abkār al-afkār fì usūl al-dīn, ed. A. H. Mahdī (Cairo, 2004), vol. 1, 335.18-336.2.

31 Abkār al-afkēr, 344.11-15.
} 
two [sc. the subject and object of self-awareness] cannot co-occur, as should be clear, nor is it impossible for the intellectual to subsist in the concrete. ${ }^{32}$

Al-Āmidī simply seizes the second horn of the dilemma: the self as known is not fully identical to the self as knowing, since the former is only a mental or "intellectual" representation whereas the latter is "concrete", that is, the person him- or herself.

\section{SELF-KNOWLEDGE AS PRESENCE}

Scholars of post-Avicennan philosophy are familiar with a rival epistemology, according to which knowledge consists in the "presence (hudūrr)" of one thing to another. This is typically associated with Suhrawardī and his Illuminationist followers, but it is terminology found already in Avicenna, and appears in many other thinkers of the period too, for instance Šaraf al-Dīn al-Mas 'ūdī (d. before 1204). In the following passage, he first names self-perception as a counterexample to Avicenna's representationalist epistemology, then offers on Avicenna's behalf the idea that self-knowledge could consist in "presence" or lack of "hiddenness":

One proof that perception is something other than contact and representation is that we perceive ourselves, that is, our perceiving faculty, which is the true reality of our souls, is knowledgeable concerning the true realities of things, knows their essences and is aware of them. Yet it is absurd that the form of us ourselves should be inscribed in ourselves. If a form corresponding to the form of our soul is established in the substance of our soul, then two forms for it would occur together, but you have learned that [for instance] two blacknesses cannot occur together in a single subject. Now if the true reality of perception is such inscribing and contact-which can be understood to occur only between two things-but there is no duality here, then there is no inscription, contact, awareness, and perception either. Yet awareness and perception do occur. Hence the true reality of awareness and perception is not the true reality of inscribing and contact.

Someone might say: the contact between the perceiving faculty and the perceived thing is perception, because the thing is occurring and present to the perceiving faculty at the moment of contact, being witnessed by it and not hidden. And the [perceived] thing is closer to itself than anything that is not present to it. So our knowing faculty is closer to itself than anything else that is present to it. It is constantly present to itself and not hidden from itself. Given that something else may be present [to the knowing faculty] when perceived by it, it is still more fitting that it itself [will be present to itself]. Inscription and contact are the presence of something [else], but our souls are present to our souls, not hidden from them. Such presence is perception, even though there is no duality or difference. ${ }^{33}$

${ }^{32}$ Kašf al-tamwīhāt fì Šarh al-Tanbīhāt, ed. A. F. Mazīdī (Beirut, 2013), 165.2-8.

33 Šukük 212.16-213.13. 
So on this theory, self-perception is not a problematic case but a paradigmatic case, since all perception involves presence of an object to a subject, and nothing is closer or more present to the subject than the subject him- or herself.

Unfortunately, al-Mas' 'üdī adds, the solution will not work, and this for two reasons. First, the notion that self-knowledge is presence cannot account for the now familiar phenomenon that in humans fully aware self-knowledge is intermittent. Second, as Āmidī also pointed out, ${ }^{34}$ self-knowledge raises a regress problem:

Another argument is that each of us would know himself, knows that he knows himself, knows that he is knowing through the knowledge that he has of himself, and so on to infinity. Obviously self-knowledge is not the same as knowledge of self-knowledge. This shows that in one of the two there is the self, in the other the knowledge of the self. Evidently, these cases of knowledge in us are in potentiality, not in actuality, though we may make them actual whenever we want. When we do this, how could it be that contact and presence arise after not having existed previously? ${ }^{35}$

His conclusion is that it is hopeless to think of self-knowledge as representational, even if the representation in question is described as "presence". Instead, we should acknowledge that "self-knowledge is different from the true reality of the self" and is something that "relates to ourselves insofar as we are knowers of ourselves and insofar as we are what is known". 36

Fahr al-Dīn too offers "presence" as a potential alternative to a representationalist account of self-knowledge, proposing it as one that might avoid the objections we've seen him posing above.

If we know ourselves, then this is either due to a form equal to ourselves being present to ourselves, or due to our own selves being present to ourselves. The former is false, for it implies the co-occurrence of indiscernibles, since neither of them differs [from the other], nor does the second more appropriately inhere in the first rather than vice-versa. As this option is false, it has been established that our knowledge of ourselves is nothing but the presence of ourselves to ourselves ( $h u d \bar{u} r$ nafsinā 'inda nafsināa). ${ }^{37}$

Al-Abharī proposes the same move, using terminology borrowed from Suhrawardì:

[Knowledge] may occur through the absence of hiddenness without the presence of a distinct essence ( $(\underline{d} \bar{a} t)$, and without the representation of its form, such as soul's perception (idrāk al-nafs) of its particular self. For soul's perception of its proper self is not through the representation of a form, since every form in the soul is universal, not par-

\footnotetext{
34 See above and compare also al-Ghazālī, Tahāfut $§ 6.37$.

35 al-Mas' ‘ùīi, Šukūk 214.7-12.

$36 \breve{S} u k \bar{u} k 214.3-4$.

37 al-Maṭālib al- 'āliyya, ed. A.H. al-Saqqā, 9 vols (Beirut, 1987), vol. 3, 120.13-17.
} 
ticular. Its perception is not the perception of its particular and specific self whose very meaning rules out that "participation" occur. The soul is the subject and the object of intellection (al-'âqil wa-l-ma'qūl). This knowledge is nothing other than the concrete being (al-huwiyya mu'ayyina) that is separate from matter. ${ }^{38}$

Notice that al-Abharī uses the concept of knowledge by presence to defend Avicenna's original claim that a self-subsisting entity or "concrete being" will be an intellect that grasps itself intellectually so long as it is immaterial.

Fahr al-Dīn, by contrast, introduces the same concept only as one move in a longer dialectical argumentation. Like al-Mas ' $\overline{\mathrm{u} d \overline{1}}$, he is not convinced that speaking of self-knowledge as a kind of presence will help Avicenna:

Suppose we agree that the presence of one separate quiddity to another separate quiddity is knowledge itself. Still, why do you say that the essence of something is present to itself? To explain: the presence of one thing to another is a specific relation between the two of them. Yet the occurrence of relation has as a precondition the difference between one entity and another. If there is no distinction, one cannot judge that something is present to itself. ${ }^{39}$

And he applies the objection to the case of God too:

Some people said that God, may He be exalted, is [not] self-knowing. They argued for this by saying that something's knowledge of something is a certain relation between the knower and the known. The occurrence of relation as a precondition the occurrence of distinction. Relation cannot occur in one thing in one and the same respect. Hence, He cannot be self-knowing. ${ }^{40}$

This line of objection relates to another way of conceiving knowledge, which developed in the kalām tradition and was endorsed by Abū l-Barakāt al-Baghdādī. According to this approach, knowledge in general should be defined as a kind of relation between the knower and the known. ${ }^{41}$ Fahr al-Dīn is inclined to accept this account, ${ }^{42}$ but sees that it causes problems for self-knowledge, because relata are always distinct. We are back with the same problem that has dogged theories of self-intellection since Plotinus, namely that knowledge requires at least a minimal difference between knower and known.

${ }^{38}$ Bayān al-asrār, ms. Istanbul, Murad Molla Kütüphanesi 1406, fol. 53v, 1. 9-14. As indicated, I translate nafs in this passage as "soul" whereas it was rendered as "self" in the previous passage from Fahr al-Dīn, as seems warranted by the different contexts.

39 Mațalib vol. 3, 121.7-11.

${ }^{40}$ Mațāilib vol. 3, 139.4-7.

${ }^{41}$ For instance at $M u$ 'tabar 323.9-10: "whoever devotes the slightest attention to the matter knows that perception of whatever kind is a relational state (hāl idā $\bar{f} \bar{\imath})$ to something perceived." See also Pines, "La conception de la conscience de soi", p. 231.

${ }^{42}$ For instance at Šarḥ al-Išārāat, ed. 'A. R. Najafzāda, 2 vols (Tehran, 2005), vol. 2, 226.9-11. 
A possible rejoinder would be to insist that a single thing can indeed enter into relations with itself. Consider for instance the relation "being identical to", as when I say that "Peter is identical to Peter." In this case it is even true to say that a lack of difference between the relata is required for the relation to obtain. Admittedly, that is a rather artificial example. Yet one can imagine other relations that admit, without requiring, identity between the relata, such as "being in the same place as" or "being the same size as". It may be trivially true and uninformative to say that I am the same size as myself, but trivial truths are still true. Might knowledge be a relation like this, one that usually involves distinct relata but can obtain between a thing and itself? This solution is found in al-Āmidī:

As for the proponent of the first doctrine, which is that if [God] knew Himself, there would be distinction between one relatum and the other, that is between the knower and the known, its soundness is undermined by our expressions "His $\underline{d} \bar{a} t$ " and "His nafs", since neither of them necessitates distinction despite the fact that a relation is realized (ma'a tahqīq al-nisba). ${ }^{43}$

When we say "His self" (we can use either $\underline{d} \bar{a} t$ or nafs to express this in Arabic), using a possessive construction (nisba), we are not suggesting that there is first God, and then a self that belongs to God. Similarly if we say that God knows Himself, we do not need to suppose that there is some distinct "self" with which God as a knower comes into relation. Fahr al-Dīn likewise suggests this solution, appealing to these same expressions: it means "agreeing with the validity of the self's relation to itself (id̄âfa al-d̄ât ilā l-nafsihā), insofar as people say 'my self' and 'your self'.",44

\section{SELF-KNOWLEDGE AND ASPECTS}

This seems to be a convincing solution, but it was not the most popular way to defend Avicenna in our period. Instead, we see many authors arguing that the subject and object of self-knowledge are distinct only insofar as they are different "aspects" or "respects" under which one and the same thing is considered. The Arabic here is i tibāra $\bar{a}$, often used in post-Avicennan philosophy to express the idea of something that is merely conceptual ( $\left.i{ }^{*} t i b \bar{a} r \bar{\imath}\right)$, as when Suhrawardī and others complain that the existence-essence distinction is one that holds only at the conceptual level. ${ }^{45}$ In the case of self-knowledge, the use of this term is already

${ }^{43}$ Rumūz al-kunūz, ms. Istanbul, Nuruosmaniye 2688, fol. 110v, 1. 7-9.

${ }^{44}$ Matălib vol. 3, 122.16-17. Compare Abū l-Barakāt's point that speaking of "my soul" is the same as speaking of "myself", discussed at Kaukua, "Self, Agent, Soul", 78.

${ }^{45}$ For conceptualism and other positions concerning existence see F. Benevich, "The EssenceExistence Distinction: Four Elements of the Post-Avicennian Metaphysical Dispute (11-13th 
found in Avicenna himself, whom we have quoted above saying that the contrast between knower and known "is nothing more than the consideration ( $i$ 'tibār $)$ that there is a quiddity existing due to itself $(l i-\underline{d} \bar{a} t i h i)$ ". ${ }^{46}$

This terminology is deployed by 'Umar ibn Sahlān al-Sāwī (d. 1145) in defending Avicenna against the polemic of al-Šarastān̄̄'s Mușāra 'a. Al-Sāwī argues that, whereas in general knowledge does involve a kind of representation or "inscribing" of something in the knower, self-knowledge is a special case. In this one case there is full identity between knower and known, with no representation needed. Any contrast between subject and object is purely a matter of different "aspects":

The demonstration that whenever anyone intellectually grasps himself, his self-intellection is not additional to himself, is as follows. As we have mentioned, intellect is the inscription of an intelligible form in the essence of the intellecting. If, however, the intelligible is the essence of the intellecting, then his form is [already] occurring, so that he does not need it to be inscribed in him once again. Otherwise, it would imply the occurrence of two things with no difference either in true reality or in something extrinsic to them in terms of accidents and attachments, but this is absurd. When we turn to our self-awareness, we find in ourselves no repetitive inscribing of our true reality or our quiddity in ourselves, so that we would be aware of [being able to] count them. Everyone who intellectually grasps himself must be aware of himself in the same way as we are. And once it is established that he intellects himself, and his intellect is his self $(\underline{d} \bar{a} t)$, not additional to himself, being intellect, intellecting, and intelligible with no multiplicity arising on the basis of these attributes (sifät), he is thus intellecting in virtue of the aspect (bi-i tibār) that he has a separate quiddity which is his self. ${ }^{47}$

In what follows, he infers from this discussion of human self-intellection that the famous triplet of 'aql, 'a qil, and ma'qūl is no threat to God's unity. Just as in the human case, with regard to God they are only "aspects ( $i$ 'tibārāt)" and so imply no multiplicity. ${ }^{48}$ It is only when the object of knowledge is distinct from the knower that knowledge is distinct from the knower's self. ${ }^{49}$ Furthermore, in keeping with Avicenna's "default" explanation of divine cognition, the three aspects are inferred only from God's negative feature of immateriality, and negative attributes imply no multiplicity. ${ }^{50}$

A prominent later defender of Avicenna who used the aspect theory in responding to the Mușāra 'a was Nașīr al-Dīn al-Ṭūsī. He invokes it against Šah-

\footnotetext{
Centuries)", Oriens 45 (2017): 203-58.

46 Šifä', Ilāhiyyāt $\$ 8.6 .12$.

${ }^{47}$ ms. Kazan 1125, 126v.6-127r.8.

48 127v.5-6.

49 128r.55-6.

50 127v.9-128r.1.
} 
rastānī's accusation that Avicenna's account sounds like the Christians' Trinitarian dogma:

These aspects amount to taking the being (huwiyya) of the Necessary insofar as it has no connection to anything else in its being, and this being belongs to this being and this being is a possession of this being. In all [these aspects] there is a single essence $(\underline{d} \bar{a} t)$, the aspects being extrinsic concomitants (lawāzim hārija) for that essence. By contrast the Christians posited a composition of three attributes - namely the hypostases of Father, Son, and the Holy Spirit - as one God. In just the same way, the Aš arites posited a composition of the essence and eight eternal attributes as one God. ${ }^{51}$

So by his count, the Aš 'arites are three times worse than the Christians, while Avicenna is the true upholder of tawhìd. Al-Ṭūsì also responds in these terms to Fahr al-Dīn's worry that if knowledge is a relation, then self-knowledge cannot involve a genuine identity between subject and object.

[R $\bar{a} z \bar{l}]$ says: The occurrence of something to something requires a difference between the two things, just like a relation of something to something or something's bestowing existence on something. This implies the impossibility of anything's knowing itself.

Answer: The difference in aspect ( $\left.i^{\text {' }} i b \bar{a} r\right)$ suffices for the occurrence [of oneself to oneself] and relation [between oneself and oneself]. For instance, whoever heals himself is, under another aspect, the one who is healed. But [difference in aspect] does not suffice for the bestowal of existence, since the bestower of existence must essentially precede that which it renders existent. ${ }^{52}$

At first glance, al-Țūsì's example seems well chosen. When a doctor cures herself, only one person is involved and this person is simply being considered from two different perspectives. We might express this using a qua operator: one and the same individual heals herself qua doctor and is healed qua patient. In the same way, the self-knower would be a subject qua knower and an object qua known. But the example looks more problematic if we look at its ultimate source, namely a passage in Aristotle's Physics (192 b 23-6) which explains that nature is a non-accidental cause:

I say "non-accidental ( $\mu$ ஸ̀ $\kappa \alpha \tau \alpha ̀ ~ \sigma v \mu \beta \varepsilon \beta \eta \kappa o ́ s)$ )" because someone might, being a doctor, be the cause of his own health; yet it would not be insofar as he is made healthy that he

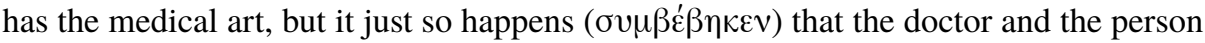
made healthy are the same.

But we presumably do not want to say, at least in God's case, that the knower and known "just happen to be" or "are accidentally" the same, rather God should be essentially self-knowing. ${ }^{53}$

51 al-Ṭūsī, Mașāri 'al-Mușāri', ed. W. Madelung (Tehran, 2004), 130.15-131.5.

52 Šarh al-Išārāt, ed. Ā. Ḥ. al-Amalī, 3 vols (Qom, Mu'assasa-yi Būstān-i Kitāb, 2004), vol. 1, 412.16-413.17. 
In any case, the "aspect" solution had not escaped the attention of Fahr al-Dīn al-Rāzì. One passage provides a particularly clear statement of the aspect theory, followed by a critical rejoinder:

Some of them said that knowledge belongs to the class of relational items. If a single self $(\underline{d} \bar{a} t)$ is taken with respect to two different attributes, it would be tantamount to two selves with regard to the relations that may correctly be realized for it. The self insofar as it is knowing is different from the self insofar as it is known. Thus relation can certainly be realized for a single self when those two aspects are different. One may reply: the two aspects due to which relation can be realized must essentially precede the realization of that relation. Something's being both knowing and known would be two relational attributes derived from the realization of knowledge. For, as long as knowledge does not occur, the attribute "knowing" does not occur to the self, nor does the attribute "known" to that which is known. Hence, the attributes of "knowing" and "known" are essentially posterior to the reality of knowledge. Yet knowledge is a relational attribute, posterior to both aspects in terms of which the occurrence of that relation is possible. If one settles the two aspects as "knowing" and "known" then they must be posterior to themselves twice over. This is absurd. ${ }^{54}$

The aspect theory suggests that the appearance of multiplicity arises only when we consider the self-related knower from two different perspectives. But this cannot be right, observes Fahr al-Dīn, because relata are prior to the relation into which they enter, not vice-versa. He makes a similar point elsewhere, concerning Avicenna's threefold description of God as 'aql, 'àqil, and ma 'qūl:

He says: This thing when taken under a certain aspect is the subject of intellection, but the object of intellection when taken under a different aspect.

Our response: If the meaning of these aspects were the same, then the expressions "subject of intellection", "intellection", and "object of intellection" would be synonymous. But an examination of synonymous words does not fit with the true realities. For we know necessarily that these expressions are not synonymous, since each of them may be true while another is false. If their meaning is not one and the same, then it is wrong to say, as he does, that something's being the subject of self-intellection is identical to himself. ${ }^{55}$

We've seen an objection like this before, when al-Šahrastānī argued against Avicenna's "default" argument that being "immaterial" cannot be the same as being "self-intellective", because otherwise these two terms would be identical in meaning and could be used interchangeably. To my mind, though, such crit-

\footnotetext{
${ }^{53}$ Perhaps al-Ṭūsĩ could take comfort from Physics 199 b 31-2, where Aristotle says that nature is like the self-healing doctor, in order to express the idea of a self-directed purposive cause. Here the focus is, at least, not on the accidental identity of cause and effect.

54 al-Mabāhith al-mašrīqiyya, ed. M. M. al-Baghdādīi, 2 vols (Beirut, 1990), 462.3-13.

${ }^{55}$ Nihāyat al-'uqūl, ed. S. 'A. L. Fūda, 4 vols (Beirut, 2015), vol. 2, 161.3-8.
} 


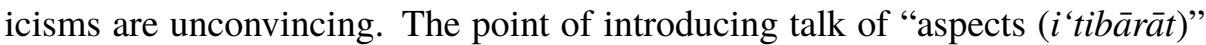
is precisely to show that we can refer to one and the same thing in a variety of ways, using terms that differ in meaning. To put it another way, the referent of 'aql, 'àqil, and ma'qūl would be extensionally identical but intensionally distinct. Notice too that these terms are not always extensionally identical. If I am thinking about giraffes, the 'a $q i l$ is me whereas the $m a$ ' $q \bar{u} l$ is giraffes, or perhaps the universal giraffe. So Fahr al-Dīn is wrong to assume that, if these three terms refer to one and the same thing in the case of self-knowledge, they must be synonymous.

Let's finally look at a passage found in one of al-Ṭūsì's students, 'Allāma alHillī (d. 1325). ${ }^{56} \mathrm{He}$ introduces a problem slightly different from anything we have seen so far, namely that first-order self-knowledge would occur together with second-order knowledge of this knowledge. Previously we saw that this sort of consideration could give rise to a regress argument, but al-Hillī instead worries that it implies a multiplicity of concurrent intellectual acts. That would not have bothered Avicenna, who explicitly says that we can accept an indefinite number of higher-order acts of self-awareness. ${ }^{57}$ Al-Hilli instead tries to solve the problem with the aspect theory.

An objection arises here, namely that if our self-intellection were the same as our selves, then our knowledge of our knowledge of ourselves would be the same as our knowledge of ourselves, which in turn would be the same as our selves, from which it would follow that multiple, distinct acts of intellection would occur all at once, which is absurd. For the occurence of one thing for another is a relation, which calls for a difference between the two things.

Some right thinking people responded that our self-knowledge is essentially the same as our selves, but different under a certain aspect. A single thing is not divided through its [mere] mental aspects when someone is considering it under these aspects, yet the difference in aspects suffices for a relation to arise.

I say: this is a matter for further inquiry. For we posit our selves, and know our selves, free from any aspects. In which case, we can ask whether they [sc. our selves and the

${ }^{56}$ On him see S. Schmitdke, The Theology of al- 'Allāma al-Hillī (d. 726 / 1325) (Berlin, 1991).

57 As discussed in Black, "Avicenna on Self-Awareness". It is interesting to note that these higher-order reflective acts were discussed in very similar terms in the Indian philosophical tradition. The Buddhist philosopher Dignāga, like Avicenna, believed that self-awareness is an ineliminable component of human mental life. He and his influential commentator Dharmakīti discuss an argument for this view to the effect that if we needed a higher-order mental act to be aware of our first-order cognitions, this would trigger an indefinite regress of acts of awareness. See on this M. MacKenzie, "The Illumination of Consciousness: Approaches to Self-Awareness in the Indian and Western Traditions", Philosophy East and West 57 (2007): 40-62; and B. Kellner, "Infinite Regress Arguments (anavasthā) in Connection with SelfAwareness (svasamvedana): a Closer Look at Dignāga and Dharmakīrti", Journal of Indian Philosophy 39 (2011): 411-26. 
knowledge of ourselves] are one and the same, or different? And one is back to the same difficulty. Maybe they would say here that an essence, in respect of its being knowing, differs from itself under the aspect of its being known. The relata are thus enumerable, and it is right to speak of relation. Yet this is weak. For here the difference presupposes knowledge, whereas in fact knowledge presupposes differentiation. [...] Those who say that knowledge is relation between the knower and the known have real trouble with this topic. $^{58}$

His concern is the same as the one expressed by Fahr al-Dīn above, namely that distinct relata are a precondition for the relation of knowledge, not the result of a merely $i$ ' $t i b \bar{a} r \bar{\imath}$ contrast between the knowing subject and knowing object.

\section{CONCLUSION}

On this and many other issues, Avicenna set the terms and context of debate for critics and defenders alike. They pursued the comparison he drew between human and divine cognition, and sometimes discussed self-awareness and selfknowledge within larger treatments of theology, for instance while treating the problem of divine attributes. Fundamentally though, the dispute charted in this paper concerned epistemology, because these later thinkers followed Avicenna's lead in exploring what seemed to be a close parallel between human and divine cognition. Self-knowledge had thus to be accommodated within more general theories of what knowledge is. For those who understood knowledge as representational or as a relation, it was a problematic and exceptional case, whereas for those who wanted to understand knowledge as "presence" it was a paradigmatic case, since we are all present to, or "not hidden from", ourselves. To my mind, a more persuasive position is one we found in al-Āmidī and Fahr al-Dīn al-Rāzî, to the effect that knowledge is indeed a relation, but relations do not necessarily require distinct relata. But perhaps it would be premature to adjudicate this dispute about self-knowledge without further discussion of the wider controversy concerning the nature of knowledge in general. All parties to that controversy might at least agree on one thing: understanding self-knowledge is more challenging than knowing oneself in the first place.

Acknowledgements. Thanks are owed to Fedor Benevich for extensive help in tracking down and translating the passages on which this presentation is based, though I take responsibility for any errors in the translations provided throughout the paper. Our work on the topic was conducted under the aegis of the DFG funded project "The Heirs of Avicenna: Philosophy in the Islamic East, $12^{\text {th }}-13^{\text {th }}$ Centuries". I am grateful for comments on an earlier draft of the paper from Benevich and also Jari Kaukua.

${ }^{58}$ Asrār al-ḩafiyya fì l-'ulūm al-'aqliyya, ed. Ḥ. M. D. al-Ālūsī and Ș. M. al-Hāšim (Beirut, 2005), 558.7-559.6. 